\title{
IMPACT OF OWNERSHIP TYPE AND FIRM SIZE ON ORGANIZATIONAL CULTURE AND ON THE ORGANIZATIONAL CULTURE-EFFECTIVENESS LINKAGE
}

\author{
Kaisheng Zeng ${ }^{1}$, Xiaohui Luo ${ }^{2}$ \\ Lingnan College, Sun Yat-sen University, 135 XinGangXi Road, \\ 510275 Guangzhou, Guangdong, P. R. China \\ E-mail: 1zengksh@mail.sysu.edu.cn (correspondingauthor),2emmylaws@gmail.com \\ Received 03 May 2012; accepted 27 November 2012
}

\begin{abstract}
This paper aims to extend the extant (primarily Western) organizational culture literature to emerging economies by explicitly incorporating two key contextual variablesownership type and firm size into organizational culture model. Based on the theoretical model developed by Denison and his colleagues, we examined the impact of ownership type and firm size on organizational culture, as well as the moderating effect of the two contextual variables on the linkage between organizational culture and firm effectiveness. Using survey data from foreign-invested and state-owned firms in China, we find that ownership type and firm size have significant influence on organizational culture. We also find that different ownership type and firm size result in different organizational cultural effect on performance.
\end{abstract}

Keywords: organizational culture, ownership type, firm size, organizational culture-effectiveness linkage, emerging economy.

Reference to this paper should be made as follows: Zeng, K.; Luo, X. 2013. Impact of ownership type and firm size on organizational culture and on the organizational culture-effectiveness linkage, Journal of Business Economics and Management 14(Supplement 1): S96-S111.

JEL Classification: M14.

\section{Introduction}

Organizational culture has received substantial attention from researchers as it is a fundamental factor affecting organizational performance (Barney, 1986; Denison, Mishra 1995; Schein 1985). Researchers have developed many organizational culture theories and models from Western contexts which are predominantly shaped by private ownership. These theories and models have been used in many studies on the relationship between organizational culture and firm outcomes (e.g. Fey, Denison 2003). However, few organizational culture studies consider ownership type and firm size which are the important factors that shape organizational behaviors and management decisions (Child, Mansfield 1972; Pugh et al. 1969). This paper attempts to extend the extant management literature by including ownership type and firm size in an organizational culture model. 
Specifically, this paper explores the following three relatively under-researched areas of organizational culture theory. Firstly, this paper examines the impact of ownership type on organizational culture. Although the effect of ownership type on such aspects of organizational life as strategic orientation and organizational structure has well been documented (e.g., Pugh et al. 1969), few studies have considered the effect of ownership type on organizational culture. As different ownership type organizations may have different levels of emphasis on organizational culture (Tan 2002), it is necessary to diagnose whether ownership type impacts firm effectiveness through organizational culture, especially when extending research into emerging economies in which firms are classified into a diversity of ownership types (Nee 1992). Secondly, this paper examines the impact of firm size on organizational culture. While research about firm size has a long history in management (Child, Mansfield 1972), there is little organizational culture comparison between small and large firms. Since firm size is an important variable and should be considered in organizational culture research (Prajogo, McDermott 2011), we suggest that the large/small firm comparison will enrich our understanding of business organizations. Thirdly, this paper provides empirical evidence of organizational culture in emerging economy. Despite considerable interest in the notion of organizational culture in emerging economies, little evidence is available in this area. Accordingly, many researchers call to investigate organizational culture models in non-western contexts, particularly in emerging economies (e.g. Denison et al. 2004).

This paper thus aims to extend the extant (primarily Western) organizational culture literature by investigating the impact of ownership type and firm size on organizational culture and on the organizational culture-effectiveness linkage. We suggest that China provides an ideal setting for this study for two important reasons. First, the transition from a centrally planned economy to a market-oriented economy has made China an archetype of emerging economies (Nee 1992). Given the inadequate knowledge of organizational culture in emerging economies, a study of firms in China is interesting and deserves attention. Second, three decades of economic reform has made China an attractive market for many multinational companies. Currently, China has different ownership type firms such as state-owned firms and foreign-invested firms. In addition, there are plenty of large and small firms operating in China. Thus, China is a good setting for the research about the effect of ownership type and firm size on organizational culture.

\section{Theoretical background and hypotheses}

\subsection{An overview of Denison's organizational culture theoretical model}

Our study uses Denison's model (Denison, Mishra 1995; Denison et al. 2004) because it is one the most popular organizational culture models and it provides a validated method of measurement of both organizational culture and effectiveness. Denison's model captures four contrasting culture traits which are represented by two axes. The first axis shows the contrast between internal integration and external adaptation orientations, and the second axis shows the contrast between flexibility and stability orientations. As shown in Figure 1, the combination of the two axes results in an archetype of culture traits in each of the four quadrants, namely involvement, consistency, adaptability and 


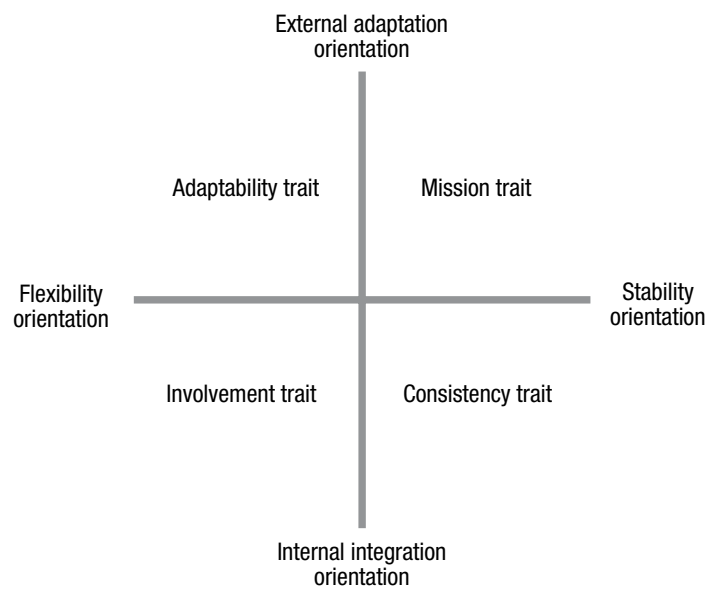

Fig. 1. Denison's theoretical model of organizational culture

mission. Denison and Mishra (1995) proposed that the involvement and consistency traits focus on internal integration orientation, while the adaptability and mission traits focus on external adaptation orientation. They also proposed that the involvement and adaptability traits reflect a flexibility orientation, while the consistency and mission traits reflect a stability orientation.

According to Denison and his colleagues, the involvement trait is characterized by (1) empowerment, (2) employee development, and (3) team orientation. They noted that involvement which focuses on internal integration can help an organization to increase employees' commitment and their sense of ownership. Similarly, the consistency trait is also a powerful source of internal integration, but it emphasizes stability. Consistency is characterized by (1) creating rules and procedures for coordination and integration, (2) common principles, and (3) common behavior norms. Denison and Mishra (1995) proposed that consistency can help an organization to promote common behavior norms and real alignment of leaders and followers. On the other hand, the adaptability trait emphasizes on flexibility and external adaptation. It is characterized by (1) creating changes to respond to external environments, (2) customer orientation, and (3) willing to take risk and learn from mistakes. Denison et al. (2004) argued that adaptability can help an organization to increase its capacity to respond to external environments and to become customer-oriented and innovative. Finally, the mission trait reflects stability and external adaptation orientations, and it is characterized by (1) explicit long-term vision, (2) clear goals, and (3) clear strategies. Fey and Denison (2003) stated that mission can help an organization to achieve its goals and to clearly inform its employees about its future direction.

Denison and Mishra (1995) argued that an organization can achieves effectiveness when it achieves both high level of internal integration and high level of external adaptation simultaneously. This argument is consistent with the 'strong culture' concept proposed by other scholars. For example, Harris (1998) used 'strong culture' to describe those 
firms which consistently share all the culture attributes in an organization. Based on above conception of culture, we consider the firms which place a high level of emphasis on all four culture traits as 'strong culture' firms and those with a low level as 'weak culture' firms. This consideration is consistent with the measurement of a strong culture used by Tsui et al. (2006).

\subsection{Ownership type and organizational culture}

This study narrows the research of ownership type down to foreign-invested firms from Anglo-cluster countries and Chinese state-owned firms, because these two types of firms are heterogeneous in terms of organizational behavior. Ronen and Shenkar (1985) identified eight country clusters including the Anglo (e.g., USA and UK) and the Far Eastern (e.g., China). They proposed that the differences between the firms from different clusters are much greater than those between the firms from the same cluster. This implies that foreign-invested firms from Anglo-cluster countries are very different from local state-owned firms. Therefore, it is important to investigate the cultural differences between these two types of firms.

Researchers suggested that foreign-invested firms face highly uncertain environments in China because they are allowed to operate only in deregulated and highly competitive industries and face changing institutional rules (Chen 1995). As a result, there is a strong need for foreign-invested firms to develop external adaptation culture for the uncertain environments. As shown in Figure 1, the external adaptation culture traits include adaptability and mission.

Adaptability, which focuses on external adaptation, is very important for foreign-invested firms. Tan (2002) found that the managers of foreign-invested firms seem to be more proactive and innovative than the managers of state-owned firms in China. This is because foreign-invested firms have to take risk to make necessary changes to meet the challenge of uncertain environments. In addition, foreign-invested firms in China seek market expansion (Chen 1995). Thus, they need to attract customers by consistently using customer-oriented strategies. On the contrary, state-owned firms are much more familiar with their local environments. The need for external adaptation is not as strong for them as it is for foreign firms. Tan (2001) found that the managers of stateowned firms worried little about risk taking because these firms are protected by the governments. Another study of Chinese state-owned firms showed that it is difficult for these firms to adopt new practices in response to the changing needs of customers (Ding et al. 2000). Thus, we expect that foreign-invested firms place greater emphasis on adaptability.

Mission, as another trait related to external adaptation, is also very important for foreign-invested firms. The concepts in mission (e.g. vision, goals and strategies) are rooted in Western management theories. These concepts have been embedded in the culture of Western firms, especially in those from Anglo-cluster countries (Trompenaars, Hampden-Turner 1998). Sharing similar characteristics with their parent companies, foreign-invested firms from Anglo-cluster countries tend to focus on explicit long-term vision, goals and strategies. Conversely, state-owned firms tend to have lower concern 
about long-term vision and goals, because they usually act as executors of the national plan rather than independent decision-making units as seen in the western nations (Child 1990). It is hence expected that foreign-invested firms place greater emphasis on mission.

Meanwhile, there is a strong need for foreign-invested firms to develop an internal integration culture, because this is a critical concern in international management. As shown in Figure 1, the internal integration orientation traits include involvement and consistency.

Involvement, as one of the internal integration traits, fits well with Anglo culture, which advocates individualism reflected as a focus on empowerment (Trompenaars, HampdenTurner 1998). The foreign-invested firms from Anglo-cluster countries are thus likely to place great emphasis on empowerment. Furthermore, to tackle the issue of internal integration, foreign-invested firms usually place great resources on training to build up shared behavior norms. On the contrary, local state-owned firms do not face such internal integration challenges. The high power distance and low individualism in Eastern culture have shaped some organizational cultural attributes in state-owned firms (Hofstede 1993). Traditionally, the decision-making processes in state-owned firms are very centralized with little empowerment. A low level of empowerment leads to low requirements of staff training. Thus, we expect that foreign-invested firms place greater emphasis on involvement.

Consistency, another trait related to internal integration, also fits well with Anglo culture which promotes control (Ronen, Shenkar 1985). Trompenaars and Hampden-Turner (1998) stated that Anglo firms usually attach great importance to control which is reflected in well-designed rules and procedures, in contrast, Eastern firms are usually family-oriented. Foreign-invested firms from Anglo-cluster countries thus tend to focus on control by using rules and procedures to shape common principles and practices among employees, while state-owned firms are more likely to use family-oriented control style which relies on the persons in power instead of relying on rules. Moreover, state-owned firms are weak in coordination and integration because the economic reform requires a restructuring of state-owned firms and the restructuring involves a long and complicated process and changes original common principles radically. It is thus expected that foreign-invested firms place greater emphasis on consistency. We therefore propose:

H1a: The four culture traits namely (1) involvement, (2) adaptability, (3) consistency and (4) mission are more significantly associated with the organizational culture of foreign-invested firms than of state-owned firms.

According to Denison's model, a firm will have a higher score in one culture trait if it put a higher level of emphasis on this trait (Denison, Mishra 1995). As a natural extension of the preceding view, an overall culture (combined) score is the sum of the scores of all traits (Yilmaz, Ergun 2008). Thus, if a firm places a higher level of emphasis on all the four culture traits, it will have a higher overall (combined) culture score which means it has a stronger organizational culture. 
As discussed in the preceding paragraphs, foreign-invested firms from Anglo countries face unfamiliar and uncertain environments in China and share similar cultural characteristics with their parent companies. Thus, they need to pay great attention to both external adaptation and internal integration. On the other hand, Chinese state-owned firms are more familiar with local environments and they can obtain more support from local governments. Accordingly, it is expected that foreign-invested firms have a higher score in each culture traits and as such have a higher overall (combined) culture score. We therefore propose:

H1b: A higher overall score (combined) score of the four culture traits is positively related to foreign-invested firms.

\subsection{Firm size and organizational culture}

As shown in Figure 1, the consistency and mission traits reflect a stability orientation. Early studies showed that large firms correlated with a formal and stable structure (e.g., Pugh et al. 1969). Later, through a review of twenty-seven studies covering more than one thousand organizations, Miller (1987) stated that organizations tended to become more formalized as their size increased. The formalization is usually reflected as more rules, procedures and control processes. Conversely, small firms tend to have an air of informality and flexibility (Mintzberg 1979). Control in small firms can be achieved relatively easily through informal face-to-face relationships (Samuel, Mannheim 1970). We hence expect that large firms are more associated with consistency.

Regarding mission, large firms have a higher capacity and necessity for setting up longterm vision, goals and strategies to maintain their advantages, because they tend to have more resources to implement their strategies and they tend to gain more market share and profitability (Quinn, Cameron 1983). On the contrary, small firms are frequently short-term oriented in terms of goals and benefits, because they are short of resources and they operate in more uncertain environments (Robbins 1990). It is thus expected that large firms are more associated with mission. We therefore propose:

H2a: The consistency and mission traits are more significantly associated with the organizational culture of large firms than of small firms.

Also in Figure 1, flexibility orientation includes two traits: involvement and adaptability. It is widely accepted that small firms tended to be more flexible (Robbins 1990). Some researchers argued that decentralization is an appropriate response to uncertain environments (Tushman, Nadler 1978). As small firms usually face highly uncertain environments, they tend to use more empowerment to adapt to the environments (Lawrence, Lorsch 1967). Conversely, large firms are more likely to emphasize centralized decision making because they face relatively certain environments (Arogyaswamy, Byles 1987). Moreover, large firms often have formal structures and hierarchies which may make them difficult to employ a flexible management style (Child, Mansfield 1972). Therefore, we expect that small firms are more associated with involvement.

Regarding adaptability, small firms are more likely to take risks to respond to external environments, where they face higher pressures and struggle for living and growing 
(Arogyaswamy, Byles 1987). In addition, small firms are frequently associated with simple structure which enables them to respond to the environments speedily (Meggison et al. 2000). Robbins (1990) argued that large firms face relatively certain environments because they tend to have more power in controlling their environments. Some scholars suggested that large firms are more risk averse and thus are more likely to emphasize a stability orientation (Aldrich, Auster 1986). Moreover, Quinn and Cameron (1983) demonstrated that large firms have a greater reliance on a formal and bureaucratic structure which may result in cautious and prudent reactions to their environments. Consequently, it is expected that small firms are more associated with adaptability. We thus propose:

H2b: The involvement and adaptability traits are more significantly associated with the organizational culture of small firms than of large firms.

\subsection{Organizational culture and firm effectiveness}

Previous studies have consistently demonstrated a positive relationship between certain organizational culture attributes and superior firm outcomes (Barney 1986; Ginevičius, Vaitkūnaitè 2006). Denison and Mishra (1995) indicated that each of the four culture traits was positively related to firm effectiveness. Denison et al. (2004) amplified the above findings by conducting two cross-cultural comparative studies in a variety of national settings and stated that the organizational culture-effectiveness linkage was both strong and consistent. In a recent study, Yilmaz and Ergun (2008) reported a significant linkage between the four culture traits and effectiveness by using data collected from the firms in Turkey. They also showed that the overall (combined) culture score positively correlates to firm effectiveness. When extending the research into Asian emerging economies such as China, we therefore expect that the culture traits have a positive impact on firm effectiveness. We thus propose:

H3a: The four culture traits namely (1) involvement, (2) adaptability, (3) consistency and (4) mission exert a significant positive effect on firm effectiveness.

H3b: The higher the overall (combined) score of the four culture traits, the higher the level of firm effectiveness will be.

\subsection{The moderating effect of ownership type and firm size on the organizational culture- effectiveness linkage}

Schein (1985) revealed that firms equally emphasizing on both internal integration and external adaptation perform best. Denison and Mishra (1995) suggested that firms become more effective when they emphasize a balanced combination of the four traits. As discussed in section 1.2, foreign-invested firms devote high level of attention to both external adaptation and internal integration. On the other hand, state-owned firms place lower level of emphasis on all four culture traits. It is thus expect that foreign-invested firms will receive more benefits from a strong organizational culture and eventually achieve superior performance. We therefore propose:

H4: The effect of organizational culture on firm effectiveness is more beneficial for foreign-invested firms than for state-owned firms. 
Denison and Mishra (1995) stated that each of the four culture traits was a significant predictor of firm effectiveness. This implies that firms can obtain benefits from the adoption of each individual culture trait. As discussed in section 1.3, large firms tend to emphasize more on consistency and mission, while small firms tend to emphasize more on involvement and adaptability. We hence expect that large firms will derive more benefits from the development of consistency and mission, while small firms will receive more benefits from the development of involvement and adaptability. We therefore propose:

H5a: The effect of the consistency and mission traits on firm effectiveness is more beneficial for large firms than for small firms.

H5b: The effect of the involvement and adaptability traits on firm effectiveness is more beneficial for small firms than for large firms.

\section{Research methods}

\section{Data collection}

A survey was employed to collect data from firms in southern China. Pilot tests were conducted to ensure that the instruments were valid and reliable. A total of 250 eligible firms were selected randomly. We contacted the selected firms and received 106 usable questionnaires. Demographic data indicate that $58 \%$ of the respondents were general managers or deputy general managers and $42 \%$ were department managers. Among the 106 samples, there are 54 foreign-invested firms and 52 state-owned firms, and there are 72 large firms and 34 small firms.

\section{Measures}

\section{Ownership type}

State-owned firms and foreign-invested firms are investigated in this study. According to Chinese laws, state-owned firms include state-owned enterprises and state-holding firms, and foreign-invested firms include Sino-foreign joint ventures, Sino-foreign cooperative enterprises and wholly owned subsidiaries of foreign multinational enterprises. We used the dummy variable-Foreign-invested vs. State-owned - in the regression analysis to compare the level of emphasis on organizational culture traits.

\section{Firm size}

Most previous studies have measured size by the number of employees (Kimberly 1976). To remain consistent with previous studies and with the demarcation in the United States and in China, we define small firms as those have fewer than 99 employees, and large firms as those have more than 500 employees. We used the dummy variable-Large vs. Small- in the regression analysis to compare the level of emphasis on organizational culture traits.

\section{Organizational culture}

Measurement scale of organizational culture was based on the scale developed by Fey and Denison (2003). The scale was subjected to back-translation procedures to detect any misunderstanding or confusion caused by translation. Respondents were required to indicate answers ranging from 1 (strongly disagree) to 7 (strongly agree) on a sevenpoint Likert scale. 


\section{Firm effectiveness}

Firm effectiveness was measured by seven five-point Likert scale items (ranging from $1=$ very poor to $5=$ very good) developed by Denison and Mishra (1995). These items included overall performance, market share, sales growth, profitability, employee satisfaction, quality of products and service, and new product development. Then the mean of these seven items is used to measure the overall effectiveness (alpha $=0.73$ ) of firms.

\section{Results}

\section{The validity and the reliability of the organizational culture measures}

As shown in Table 1, the data factor nicely into four dimensions of organizational culture with relatively high factor loadings ( most around 0.7 and above) and low cross loadings ( most below 0.2). Thus, good convergent and discriminate validity of the measures is achieved. In addition, the Cronbach's alphas for involvement, consistency, adaptability and mission are $0.75,0.74,0.83$ and 0.89 respectively, and the alpha of overall culture score reaches to 0.90 . Because all the Cronbach's alphas are greater than 0.7 , this indicates a very good reliability of the measures. Moreover, the correlations matrix in Table 2 shows the high correlations among the four traits (around 0.2 to 0.5 ) without multicollinearity problems.

Table 1. Factor analysis of organizational culture measures

\begin{tabular}{lccccc}
\hline & Factor 1 & Factor 2 & Factor 3 & Factor 4 & Cronbach's Alpha \\
\hline OCIN2 & 0.162 & 0.103 & 0.215 & $\mathbf{0 . 7 5 6}$ & $\mathbf{0 . 7 5}$ \\
\hline OCIN3 & 0.271 & 0.226 & 0.193 & $\mathbf{0 . 6 0 3}$ & \\
\hline OCIN5 & 0.349 & 0.211 & 0.083 & $\mathbf{0 . 5 2 7}$ & $\mathbf{0 . 7 4}$ \\
\hline \multicolumn{5}{c}{ Consistency } \\
\hline OCCO2 & -0.040 & 0.167 & $\mathbf{0 . 7 3 5}$ & 0.075 & \\
\hline OCCO3 & 0.035 & 0.249 & $\mathbf{0 . 5 2 8}$ & 0.213 & \\
\hline OCCO4 & 0.112 & 0.251 & $\mathbf{0 . 6 8 8}$ & 0.154 & \\
\hline OCAD1 & $\mathbf{0 . 7 1 3}$ & 0.145 & 0.018 & 0.273 & \\
\hline OCAD2 & $\mathbf{0 . 6 3 0}$ & 0.180 & 0.237 & 0.213 & \\
\hline OCAD3 & $\mathbf{0 . 8 6 9}$ & 0.333 & 0.050 & 0.029 & \\
\hline OCAD4 & $\mathbf{0 . 5 9 8}$ & 0.120 & -0.081 & 0.233 & \\
\hline OCMIability & & \\
\hline OCMI2 & 0.234 & $\mathbf{0 . 6 2 3}$ & 0.334 & 0.298 \\
\hline OCMI3 & 0.209 & $\mathbf{0 . 7 2 1}$ & 0.319 & 0.086 & $\mathbf{0 . 9 0}$ \\
\hline OCMI4 & 0.282 & $\mathbf{0 . 7 3 6}$ & 0.161 & 0.345 & \\
\hline & & Mission & & & \\
\hline
\end{tabular}

Note: $\mathrm{N}=106$. 
Table 2. Correlation matrix (Pearson Coefficients)

\begin{tabular}{|c|c|c|c|c|c|c|c|}
\hline & 1 & 2 & 3 & 4 & 5 & 6 & 7 \\
\hline \multicolumn{8}{|l|}{ 1. Involvement } \\
\hline 2. Consistency & $0.384 * * *$ & & & & & & \\
\hline 3. Adaptability & $0.526^{* * *}$ & $0.192 *$ & & & & & \\
\hline 4. Mission & $0.517 * * *$ & $0.534 * * *$ & $0.504 * * *$ & & & & \\
\hline $\begin{array}{l}\text { 5. Overall culture } \\
\text { score }\end{array}$ & $0.800 * * *$ & $0.689 * * *$ & $0.725 * * *$ & $0.838 * * *$ & & & \\
\hline $\begin{array}{l}\text { 6. Overall } \\
\text { Effectiveness }\end{array}$ & $0.276^{* *}$ & $0.358 * * *$ & $0.449 * * *$ & $0.487 * * *$ & $0.512 * * *$ & & \\
\hline 7. Large vs. Small & 0.109 & $0.263 * *$ & $0.271 * *$ & $0.286^{* *}$ & $0.302 * *$ & $0.307 * * *$ & \\
\hline $\begin{array}{l}\text { 8. Foreign-invested } \\
\text { vs. State-owned }\end{array}$ & $0.221 *$ & $0.337 * * *$ & 0.042 & $0.303 * *$ & $0.297 * *$ & $0.210 *$ & $0.215^{*}$ \\
\hline
\end{tabular}

Notes: $* \mathrm{p}<0.05, * * \mathrm{p}<0.01, * * * \mathrm{p}<0.001 ; \mathrm{N}=106$.

Hypothesis 1 and 2: effects of ownership type and firm size on organizational culture The result of regression analyses in Table 3 reveals the effects of ownership type and firm size on each culture traits and on the overall culture score. All regression models explain some portion of the observed variances in the culture traits and overall culture score, with the $\mathrm{R}^{2} \mathrm{~s}$ ranging from $5 \%$ to $15 \%$ and the $F$-statistic ranging from 2.9 to 9 (d.f. $=2 ; 103$ ). As to ownership type, the data shows that foreign-invested firms are more related to three culture traits, namely involvement, consistency and mission. The data also shows that there is no difference between the two types of firms for the adaptability trait. Furthermore, the data shows that a higher overall culture score is significantly associated with foreign-invested firms. This result provides partial support to H1a and full support to H1b.

Table 3. The effects of ownership type and firm size on culture traits

\begin{tabular}{lccccc}
\hline \multicolumn{1}{c}{ Predictors } & Involvement & Consistency & Adaptability & Mission & $\begin{array}{c}\text { Overall } \\
\text { culture score }\end{array}$ \\
\hline $\begin{array}{l}\text { Foreign-invested } \\
\text { vs. State-owned }\end{array}$ & $0.207^{* *}$ & $0.2-94^{* * *}$ & -0.017 & $0.253^{* * *}$ & $0.243^{* * *}$ \\
\hline Large vs. Small & 0.064 & $0.200^{* *}$ & $0.275^{* * *}$ & $0.231^{* *}$ & $0.250^{* * *}$ \\
\hline $\mathrm{F}$ & $2.872^{*}$ & $9.217^{* * *}$ & $4.109^{* *}$ & $8.585^{* * *}$ & $8.919^{* * *}$ \\
\hline $\mathrm{R}^{2}$ & $5.3 \%$ & $15.2 \%$ & $7.4 \%$ & $14.3 \%$ & $14.8 \%$ \\
\hline Adjusted $\mathrm{R}^{2}$ & $3.4 \%$ & $13.5 \%$ & $5.6 \%$ & $12.6 \%$ & $13.1 \%$ \\
\hline $\mathrm{DF}$ & 2,103 & 2,103 & 2,103 & 2,103 & 2,103 \\
\hline
\end{tabular}

Notes: ${ }^{*} \mathrm{p}<0.1,{ }^{*} \mathrm{p}<0.05, * * * \mathrm{p}<0.01 ; 1$ standardized regression coefficients (Betas) are reported; $2 . \mathrm{N}=106$. 
With regard to firm size, the data shows that large firms are more associated with three culture traits, namely consistency, adaptability and mission. The data also shows that there is no difference between large and small firms concerning the involvement trait. Hence, $\mathrm{H} 2 \mathrm{a}$ is supported and $\mathrm{H} 2 \mathrm{~b}$ is rejected.

\section{Hypothesis 3: analysis of organizational culture-effectiveness linkage}

In Table 2, the correlations offer support for both H3a and H3b. All of the four culture traits and the overall culture score are significantly positively related to firm effectiveness. A more definitive look at the organizational culture-effectiveness linkage is provided by the regression result in Table 4 . Table 4 shows that all culture traits except involvement are significant predictors of firm effectiveness. Moreover, Table 4 shows that adaptability seems to be the most important determinants of firm effectiveness because it is the culture trait most highly associated with effectiveness. Hence, both H3a and $\mathrm{H} 3 \mathrm{~b}$ are supported.

Table 4. Result of regression analyses for culture traits on firm effectiveness

\begin{tabular}{lc}
\hline \multicolumn{1}{c}{ Predictors } & Overall Effectiveness \\
\hline Involvement & -0.116 \\
\hline Consistency & $0.190^{*}$ \\
\hline Adaptability & $0.333^{* * *}$ \\
\hline Mission & $0.278^{* *}$ \\
\hline $\mathrm{F}$ (full model) & $11.927 * * *$ \\
\hline $\mathrm{R}^{2}$ & $32.1 \%$ \\
\hline Adjusted $\mathrm{R}^{2}$ & $29.4 \%$ \\
\hline $\mathrm{DF}$ & 4,101 \\
\hline
\end{tabular}

Notes: ${ }^{*} \mathrm{p}<0.1,{ }^{* *} \mathrm{p}<0.05, * * * \mathrm{p}<0.01 ; 1$ standardized regression coefficients (Betas) are reported; $2 . \mathrm{N}=106$.

\section{Hypothesis 4 and 5: moderating effect of ownership type and firm size}

Because the independent variables are categorical variables and the dependent variable is a continuous variable, grouped regression analysis is suitable for testing the moderating effect of ownership type and firm size on the organizational culture-effectiveness linkage (Cohen et al. 2003).

Table 5 reports the moderating effect of ownership type. As shown in Table 5, all regression models, except for the interaction between involvement and state-owned firms, have a significant $F$-statistic ranging from 2.99 to 20 . In line with our expectation, the regression coefficient of all the equations about foreign-invested firms is significantly positive which means that the effect of organizational culture on firm effectiveness is highly beneficial for foreign-invested firms. Contrary to our expectation, however, state-owned firms can also derive benefit from the adoption of three of the four culture traits-consistency, adaptability and mission, though they have relatively lower overall culture score. Thus, H4 is rejected. 


\begin{tabular}{|c|c|c|c|c|c|c|}
\hline \multirow{2}{*}{ Predictors } & $\begin{array}{l}\text { State-owned } \\
\text { firms }\end{array}$ & $\begin{array}{c}\text { Foreign- } \\
\text { invested firms }\end{array}$ & & & & \\
\hline & $\begin{array}{c}\text { Overall } \\
\text { Effectiveness }\end{array}$ & $\begin{array}{c}\text { Overall } \\
\text { Effectiveness }\end{array}$ & $\mathrm{F}$ & $\mathrm{R}^{2}$ & $\begin{array}{l}\text { Adjusted } \\
\mathrm{R}^{2}\end{array}$ & DF \\
\hline \multicolumn{7}{|c|}{ Moderating effects } \\
\hline $\begin{array}{l}\text { Involvement } \times \\
\text { State-owned }\end{array}$ & 0.217 & & 2.475 & $4.7 \%$ & $2.8 \%$ & 1,50 \\
\hline $\begin{array}{l}\text { Involvement } \times \\
\text { Foreign-invested }\end{array}$ & & $0.266^{*}$ & $3.962 *$ & $7.1 \%$ & $5.3 \%$ & 1,52 \\
\hline $\begin{array}{l}\text { Consistency } \times \\
\text { State-owned }\end{array}$ & $0.238^{*}$ & & $2.992 *$ & $5.6 \%$ & $3.8 \%$ & 1,50 \\
\hline $\begin{array}{l}\text { Consistency } \times \\
\text { Foreign-invested }\end{array}$ & & $0.400 * * *$ & $9.898 * * *$ & $16.0 \%$ & $14.4 \%$ & 1,52 \\
\hline $\begin{array}{l}\text { Adaptability } \times \\
\text { State-owned }\end{array}$ & $0.534 * * *$ & & $19.928 * * *$ & $28.5 \%$ & $27.1 \%$ & 1,50 \\
\hline $\begin{array}{l}\text { Adaptability } \times \\
\text { Foreign-invested }\end{array}$ & & $0.364 * * *$ & $7.941 * * *$ & $13.2 \%$ & $11.6 \%$ & 1,52 \\
\hline Mission $\times$ State-owned & $0.447 * * *$ & & $12.519 * * *$ & $20.0 \%$ & $18.4 \%$ & 1,50 \\
\hline $\begin{array}{l}\text { Mission } \times \\
\text { Foreign-invested }\end{array}$ & & $0.470 * * *$ & $14.775 * * *$ & $22.1 \%$ & $20.6 \%$ & 1,52 \\
\hline
\end{tabular}

Notes: ${ }^{*} \mathrm{p}<0.1,{ }^{* *} \mathrm{p}<0.05,{ }^{* *} \mathrm{p}<0.01 ; 1$ standardized regression coefficients (Betas) are reported; $2 . \mathrm{N}=106$.

Table 6 reports the moderating effect of firm size. For large firms, the data shows that all regression models have a significant $F$-statistic ranging from 9.67 to 25.2, and all the two-way interactions with each culture trait are positively associated with effectiveness. This result indicates that large firms can derive benefit from developing all culture traits. As for small firms, only the two-way interaction with the mission trait is positively related to effectiveness. This result indicates that small firms probably cannot benefit from the adoption of involvement and adaptability traits. Thus, H5a is partially supported and $\mathrm{H} 5 \mathrm{~b}$ is rejected.

\section{Discussions and conclusions}

In this study, based on Denison's four-culture-traits model, we investigated the relationship between organizational culture and ownership type and firm size. We also investigated the moderating effect of ownership type and firm size on the organizational culture-effectiveness linkage.

We find that, compared with state-owned firms, foreign-invested firms place more emphasis on the involvement, consistency and mission traits and they have higher overall culture scores. The findings imply that foreign-invested firms have stronger organizational culture than state-owned firms. One possible reason for this result is that foreign- 
Table 6. Result of regression analyses for moderating effect of firm size

\begin{tabular}{|c|c|c|c|c|c|c|}
\hline \multirow{2}{*}{ Predictors } & Small firms & \multicolumn{5}{|l|}{ Large firms } \\
\hline & $\begin{array}{c}\text { Overall } \\
\text { Effectiveness }\end{array}$ & $\begin{array}{c}\text { Overall } \\
\text { Effectiveness }\end{array}$ & $\mathrm{F}$ & $\mathrm{R}^{2}$ & $\begin{array}{l}\text { Adjusted } \\
\mathrm{R}^{2}\end{array}$ & DF \\
\hline \multicolumn{7}{|c|}{ Moderating effects } \\
\hline Involvement $\times$ Small & 0.014 & & 0.007 & $0.0 \%$ & $-3.1 \%$ & 1,32 \\
\hline Involvement $\times$ Large & & $0.348 * * *$ & $9.669 * * *$ & $12.1 \%$ & $10.9 \%$ & 1,70 \\
\hline Consistency $\times$ Small & 0.119 & & 0.464 & $1.4 \%$ & $-1.7 \%$ & 1,32 \\
\hline Consistency $\times$ Large & & $0.383 * * *$ & $12.053 * * *$ & $14.7 \%$ & $13.5 \%$ & 1,70 \\
\hline Adaptability $\times$ Small & 0.242 & & 1.989 & $5.9 \%$ & $2.9 \%$ & 1,32 \\
\hline Adaptability $\times$ Large & & $0.453 * * *$ & $18.084 * * *$ & $20.5 \%$ & $19.4 \%$ & 1,70 \\
\hline Mission $\times$ Small & $0.451 * * *$ & & $8.159 * * *$ & $20.3 \%$ & $17.8 \%$ & 1,32 \\
\hline Mission $\times$ Large & & $0.434 * * *$ & $16.207 * * *$ & $18.8 \%$ & $17.6 \%$ & 1,70 \\
\hline
\end{tabular}

Notes: ${ }^{*} \mathrm{p}<0.1,{ }^{* *} \mathrm{p}<0.05,{ }^{* * *} \mathrm{p}<0.01 ; 1$ standardized regression coefficients (Betas) are reported; $2 . \mathrm{N}=106$.

invested firms share similar cultural characteristics with their Western parent companies which usually have strong organizational culture (Trompenaars, Hampden-Turner 1998). The organizational culture in the Western parent companies is brought to their foreign subsidiaries by the top management team. Hence, foreign-invested firms usually already have strong organizational culture when they are set up.

A more interesting finding is that both foreign-invested and state-owned firms put high emphasis on the adaptability trait. In addition, Table 4 demonstrates that firm effectiveness is most highly associated with the adaptability trait. The combined results imply that adaptability seem to be the most important determinant of effectiveness for both foreign-invested and state-owned firms. This finding makes good intuitive sense, given China's dynamic environments. This finding is also in line with Daft's (2007) argument that adaptability culture fits best if external environments are uncertain and require flexibility. As described by Denison and Mishra (1995), the adaptability trait focuses on developing capacity for creating changes in response to uncertain external environments. Hence, adaptability is appropriate for both foreign-invested and state-owned firms to operate in the situation of uncertainty.

We also find that, compared with small firms, large firms place more emphasis on consistency and mission. However, in contrast to our expectation, small firms fail to put more emphasis on involvement and adaptability, while a higher level of adaptability has been seen in large firms. There are two possible reasons for these results. First, although involvement and adaptability are strongly required by small firms, it is the large firms that tend to have more resources to "create" internal changes in response to external environmental changes. Second, although small firms may be much more willing to take risks, to decentralize control in order to react to the uncertain environments, it is the 
large firms that tend to have more expertise to "select" appropriate strategies to react to the external uncertainty.

We have two interesting findings about the moderating effect of firm size and ownership type on the organizational culture-effectiveness linkage. One interesting finding concerns the moderating effect of ownership type. Consistent with our expectation, foreign-invested firms derive benefits from adopting all the four culture traits. However, in contrast to our expectation, although state-owned firms have lower culture scores, they get benefits from the adoption of all the culture traits except involvement. An implication of this finding is that state-owned firms are willing to put resources in developing strong organizational culture for future benefits, though they have a relatively weak organizational culture at present. One possible reason for this is that state-owned firms need to accelerate their modernization which is characterized by the adoption of Western management practices such as building up strong organizational culture.

Another interesting finding is about the moderating effect of firm size. Our findings indicate that large firms can achieve superior performance through adopting all culture traits, while small firms can only get benefit from the mission trait. An implication of this finding is that large firms can derive benefits from strong organizational culture, while small firms cannot. One possible reason for this result is that small firms usually face difficulties in terms of survival and they often lack resource and expertise. They need to invest their limited resources into solving urgent operational problems, and they usually have no extra manpower, financial and other resources to develop strong organizational culture. Another possible reason is that the development of strong organizational culture is often time consuming without immediate effect, so small firms may not be willing to invest in it and thus the effect of it cannot be reflected.

Overall, our study makes several significant contributions. Firstly, it extends the organizational culture model by introducing two key contextual variables, i.e. ownership type and firm size, into the research. Secondly, it extends "Western" organizational culture literature to an "Eastern" cultural context by examining the organizational culture model in China. Thirdly, it reveals the effect of firm size and ownership type on the organizational culture-effectiveness linkage. Finally, our study conveys novel messages to managers about how different firm size and ownership type affect organizational culture.

\section{References}

Aldrich, H. E.; Auster, E. 1986. Even dwarfs started small: liabilities of size and age and their strategy implications, in B. M. Staw, L. L. Cummings (Eds.). Research in organizational behavior. Greenwich, CT: JAI Press. 8, 165-198.

Arogyaswamy, B.; Byles, C. M. 1987. Organizational culture: internal and external fits, Journal of Management 13(4): 647-659. http://dx.doi.org/10.1177/014920638701300406

Barney, J. B.1986. Organizational culture: can it be a source of sustained competitive advantage?, Academy of Management Review 11(3): 656-665.

Chen, C. C. 1995 . New trends in rewards allocation preferences: a Sino-U.S. comparison, Academy of Management Journal 38(2): 408-424. http://dx.doi.org/10.2307/256686

Child, J.; Mansfield, R. 1972. Technology, size and organizational structure, Sociology 6: 369-393. 
Child, J. 1990. The character of Chinese enterprise management, in S. Stewart, A. Carver (Eds.). Advances in Chinese Industrial Studies, 1. Greenwich, CT: JAI Press.

http://dx.doi.org/10.1177/003803857200600304

Cohen, J.; Cohen, P.; West, S. G.; Aiken, L. S. 2003. Applied multiple regression / correlation analysis for the behavioral sciences. 3rd ed. Hillsdale, NJ: Erlbaum.

Daft, R. L. 2007. Organization theory and design. 9th ed. Cincinnati, OH: South-Western.

Denison, D. R.; Mishra, A. K. 1995. Toward a theory of organizational culture and effectiveness, Organizational Science 6: 204-223. http://dx.doi.org/10.1287/orsc.6.2.204

Denison, D. R.; Haaland, S.; Goelzer, P. 2004. Corporate culture and organizational effectiveness: is Asia different from the rest of the World?, Organizational Dynamics 33(1): 98-109.

http://dx.doi.org/10.1016/j.orgdyn.2003.11.008

Ding, D. Z.; Goodall, K.; Warner, M. 2000. The end of the "iron rice-bowl": whither Chinese human resource management?, International Journal of Human Resource Management 11: 217-36. http://dx.doi.org/10.1080/095851900339837

Fey, C.; Denison, D. R. 2003. Organizational culture and effectiveness: can American theory be applied in Russia?, Organization Science 14(6): 686-706.

http://dx.doi.org/10.1287/orsc.14.6.686.24868

Ginevičius, R.; Vaitkūnaite, V. 2006. Analysis of organizational culture dimensions impacting performance, Journal of Business Economics and Management 7(4): 201-211.

Harris, L. 1998. Cultural domination: the key to market-oriented culture?, European Journal of Marketing 32(March): 354-373. http://dx.doi.org/10.1108/03090569810204643

Hofstede, G. 1993. Cultural constraints in management theories, Academy of Management Executive 7(1): 81-94.

Kimberly, J. R. 1976. Organizational size and the structuralist perspective: a review, critique, and proposal, Administrative Science Quarterly 21(4): 571-597.

http://dx.doi.org/10.2307/2391717

Lawrence, P. R.; Lorsch, J. 1967. Organization and environment. Boston, MA: Harvard Business School, Division of Research.

Meggison, W.; Byrd, M.; Emeritus, L. 2000. Small business management. Boston: McGraw-Hill. Miller, G. A. 1987. Meta-analysis and Culture-free Hypothesis, Organization Studies 8(4): 309326. http://dx.doi.org/10.1177/017084068700800402

Mintzberg, H. 1979. The structuring of organizations. Englewood Cliffs, N.J.: Prentice-Hall.

Nee, V. 1992. Organizational dynamics of market transition: hybrid forms, property rights, and mixed economy in China, Administrative Science Quarterly 37(1): 1-27.

http://dx.doi.org/10.2307/2393531

Prajogo, D. I.; McDermott, C. M. 2011. The relationship between multidimensional organizational culture and performance, International Journal of Operations \& Production Management 31(7): 712-735. http://dx.doi.org/10.1108/01443571111144823

Pugh, D. S.; Hickson, D. J.; Hinings, C. R. 1969. An empirical taxonomy of structures of work organizations, Administrative Science Quarterly 14(1): 115-126. http://dx.doi.org/10.2307/2391367

Quinn, R. E.; Cameron, K. 1983. Organizational life cycles and shifting criteria of effectiveness: some preliminary evidence, Management Science 29: 33-51.

http://dx.doi.org/10.1287/mnsc.29.1.33

Robbins, S. P. 1990. Organization theory: structure, design, and applications. NJ: Prentice-Hall. Ronen, S.; Shenkar, O. 1985. Clustering countries on attitudinal dimensions, Academy of Management Review 10: 449-455. 
Samuel, Y.; Mannheim, B. F. 1970. A multidimensional approach toward a typology of bureaucracy, Administrative Science Quarterly 15(2): 216-228. http://dx.doi.org/10.2307/2391492

Schein, E. H. 1985. Organizational culture and leadership. San Francisco, CA: Jossey-Bass.

Tan, J. 2001. Are managers and entrepreneurs different in innovation and risk taking?: a comparative study in China's transition economy, Journal of Business Venturing 16(4): 359-376. http://dx.doi.org/10.1016/S0883-9026(99)00056-7

Tan, J. 2002. Impact of ownership type on environment-strategy linkage and performance: evidence from a transitional economy, Journal of Management Studies 39(3): 333-354.

Trompenaars, F.; Hampden-Turner, C. 1998. Riding the waves of culture: understanding cultural diversity in global business. 2nd ed. New York: McGraw-Hill.

Tsui, A. S.; Zhang, Z. X.; Xin , K. R.; Wu, J. B. 2006. Unpacking the relationship between CEO leadership behavior and organizational culture, The Leadership Quarterly 17: 113-137.

http://dx.doi.org/10.1016/j.leaqua.2005.12.001

Tushman, M. L.; Nadler, D. A. 1978. Information processing as an integrating concept in organizational design, Academy of Management Review 3(1): 613-624.

Yilmaz, C.; Ergun, E. 2008. Organizational culture and firm effectiveness: an examination of relative effects of culture traits and the balanced culture hypothesis in an emerging economy, Journal of World Business 43: 290-306. http://dx.doi.org/10.1016/j.jwb.2008.03.019

Kaisheng ZENG. PhD, is an Associate professor at Lingnan College, Sun Yat-Sen University, China. His teaching and research interests are international business and management. He has publications in national and international journals.

Xiaohui LUO. A former editor of a national journal. Her research areas are management and accounting. She has publications in national and international journals. 